\title{
Management of Traumatic Cardiac Arrest from hypovolaemia: is there a consensus?
}

\author{
Naomi Pritchard", Rosel Tallach \\ From London Trauma Conference 2014 \\ London, UK. 9-12 December 2014
}

\section{Background}

The survival rates of Traumatic Cardiac Arrest (TCA) from hypovolaemia remain poor. The underlying pathology differs from medical cardiac arrest and therefore necessitates different management. This has been described in the pre-hospital and resuscitation room setting.

Our hypothesis was that response to cardiac arrest from exsanguinating haemorrhage varied widely when it occurred downstream of the emergency department. We gleaned national opinion on how to manage this pathology when it occurred in transit to, or in, the operating theatre.

\section{Method}

A telephone/email survey of all English major trauma centres (MTCs) asked two questions:

1) Did their MTC have an algorithm for in-hospital TCA differing from the ALS cardiac arrest algorithm?

2) If a patient arrested from presumed ongoing haemorrhage, would they receive cardiopulmonary resuscitation (CPR), Adrenaline or just continued filling?

\section{Results}

14 out of 22 MTCs responded. 3 have protocols specifically for in-hospital TCA, all differing significantly.

Responses from the other 10 MTCs varied. 5 centres follow ALS medical protocols and commence CPR. 1 centre would start CPR, but stop for thoracotomy in the case of penetrating trauma. Of those centres not starting CPR, 3 undertake thorocotomy to achieve aortic compression. 2 centres decide on a case to case basis.

ALS protocol followers use $1 \mathrm{mg}$ Adrenaline. Some centres give 'some' Adrenaline, 7 centres don't give

\footnotetext{
* Correspondence: pritchardnaomi@hotmail.com

Department of Anaesthetics, The Royal London Hospital, Barts Health, London, UK
}

(C) 2015 Pritchard and Tallach This is an Open Access article distributed under the terms of the Creative Commons Attribution License (http://creativecommons.org/licenses/by/4.0), which permits unrestricted use, distribution, and reproduction in any medium, provided the original work is properly cited. The Creative Commons Public Domain Dedication waiver (http://creativecommons.org/ publicdomain/zero/1.0/) applies to the data made available in this article, unless otherwise stated.
Adrenaline. 1 centre didn't know if they would or not. Nowhere favoured just filling and no other action.

\section{Conclusion}

There is no consensus on in-hospital treatment of TCA caused by hypovolaemia.

Wide variations in staff training and experience influences TCA management nationally. While much training has been invested in emergency physicians, this training has not extended to anaesthetists who are the team leaders downstream of the emergency department. Confusion regarding the resuscitation from haemorrhage/ hypovolaemia may contribute to its high mortality.

Published: 11 September 2015

\section{doi:10.1186/1757-7241-23-S2-A11}

Cite this article as: Pritchard and Tallach: Management of Traumatic Cardiac Arrest from hypovolaemia: is there a consensus? Scandinavian Journal of Trauma, Resuscitation and Emergency Medicine 2015 23(Suppl 2): A11.
Submit your next manuscript to BioMed Central and take full advantage of:

- Convenient online submission

- Thorough peer review

- No space constraints or color figure charges

- Immediate publication on acceptance

- Inclusion in PubMed, CAS, Scopus and Google Scholar

- Research which is freely available for redistribution

Submit your manuscript at Submit your manuscript at

C BioMed Central 